\title{
THE EFFECT OF GENOTYPE AND HOUSING SYSTEM ON PRODUCTION RESULTS OF FATTENING CHICKENS
}

\author{
Z. Pavlovski, Z. Škrbić, M. Lukić, V. Petričević, S. Trenkovski \\ Institute for Animal Husbandry, Belgrade-Zemun, Serbia \\ Corresponnding author: \\ Zlatica Pavlovski, e-mail: zlaticapav@yahoo.com \\ Original scientific paper
}

Abstract: Investigation was carried out on 500 Arbor Acres and Redbro chickens. First group of 30 male and female chickens per genotype was slaughtered after $12 \mathrm{~h}$ period of food deprivation. Second group remained in the facility and was fattened until 50. day. Third group was reared for 50 days but in a semi intensive system, with use of $20 \mathrm{~m}^{2}$ and free range area of $1 \mathrm{~m}^{2} / \mathrm{bird}$. Nutrition was based on mixture of ground corn, barley, vitmain mineral additive and $30 \%$ of complete forage mixture. All chickens, subsequent to finished fattening period (50 days) were weighed and after $12 \mathrm{~h}$ food deprivation period were slaughtered. Arbor Acres chickens at the age of 42 days had lower mortality $(3.80 \%)$, better feed conversion (1.868) and higher realized value of production index (206.73) compared to Redbro chickens. Chickens reared in the facility have realized considerably higher body mass $(1820.33 \mathrm{~g})$ compared to free range chickens $(1667.50 \mathrm{~g})$. Chickens at the age of 50 days had higher carcass yield comapred to chcikens at the age of 42 days. Carcass yields "traditional processing" and "ready to roast" were considerably higher in chickens at the age of 50 days (83.53 and 76.59) compared to carcass yields of chickens at the age of 42 days (82.61 and 75.68). Chickens reared in the facility (chicken coop) (83.86) had higher carcass yields "traditional processing" than free range chickens. Other yields in chickens were considerably higher in chickens reared in the facility (76.56 and 67.13) than in free range chickens (75.76 and 65.45).

Key words: housing system, genotype, broiler, production traits

\section{Introduction}

Modern poultry production requires constant innovating of the technological process of production, because of improvement of the economical efficiency as well as satisfying the market demand for new and different products, all in accordance to consumer demnads. On the other hand, intensive broiler production is criticized because of the lack of consideration of animal welfare. 
Relatively poorer quality of chicken meat deriving from industrial prodcution (broilers with watery meat, often without taste and excessive fat), sudden decrease of the price, with ample offer on the market and certain nostalgia for good old times have maybe influenced opinion of people that poultry products produced in the industrial way are not healthy and natural. Supporters of animal welfare and animal protection ("Green" party, people who prefer natural foods) are fighting against housing of poultry in closed, dark and crowded space. There is increasing demand for return to the nature which would be accomplished by application of new housing systems and slow growing hybrids. Many researchers have investigated new housing systems and different genotypes and their effect on production results (Vračar et al.,1996; Hopić et al.,1996; Melo et al.,1996; Lewis et al.,1997; Grashorn and Clastermann, 2002; Grashorn, 2004; Pavlovski et al.,2001; Perić et al.,2003; Milošević et al., 2005; Škrbić et al., 2008; Škrbić et al., 2009; Vitorović et al. 2008) and established that housing system and genotype have influence on certain production results, meat quality and firmness of broiler bones.

Objective of this research was to investigate the effect of age, genotype (Redbro and Arbor Acres), sex and housing system (intensive and semi intensive) on production traits of fattening chickens.

\section{Materials and methods}

Investigation was carried out on 500 chickens of Arbor Acres and Redbro genotype, which were identified with wing tags and housed in separated boxes $\left(17 / \mathrm{m}^{2}\right)$. Nutrition and watering was ad libitum. During the period from 1. to 10 . day, chickens were fed complete forage mixtures with $23 \% \mathrm{CP}$ and $12.85 \mathrm{ME}$, from 11.-28. day with $21 \% \mathrm{CP}$ and $13.25 \% \mathrm{ME}$, and in the period from 29.-42. day mixtures containing 19\% CP and $13.50 \mathrm{ME}$. During trial, to the 42 day of fattening, daily the mortality and feed consumption were recorded. After 42 days of fattening, chickens were weighed individually and 90 chickens of both sexes and both genotypes Arbor Acres and Redbro were randomly selected. Based on average body masses three groups of chickens were formed with 30 chickens of both sexes (15 males and 15 males) and both genotypes (Arbor Acres and Redbro).

First group of 30 male and female chickens per genotype was slaughtered after $12 \mathrm{~h}$ period of food deprivation. Second group remained in the facility and was fattened until 50. day. Third group was reared for 50 days but in a semi intensive system, with use of $20 \mathrm{~m}^{2}$ and free range area of $1 \mathrm{~m}^{2} / \mathrm{bird}$. Nutrition was based on mixture of ground corn, barley, vitmain mineral additive and $30 \%$ of complete forage mixture. All chickens, subsequent to finished fattening period (50 days) were weighed and after $12 \mathrm{~h}$ food deprivation period were slaughtered. 
Carcasses of slaughtered chickens were processed according to valid Regulation/Rulebook on quality of poultry meat in Serbia, and the following carcasses were obtained:

- Traditional processing - carcass with head, neck, lower leg parts and edible internal organs;

- Ready to roast - carcass with lungs and kidneys, with neck skin, heart, liver, stomach and spleen;

- Ready to grill - carcass with lungs and kidneys.

Following conformation measures were taken: tarsus/shank length, keel length, breast depth, thigh girth and breast angle, according to method by Pavlovski and Mašić (1983).

Based on data on body mass, feed conversion and mortality, value of production index was calcultated according to following formula:

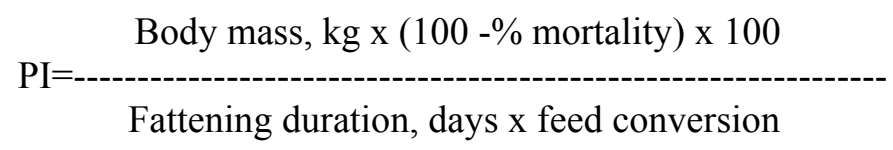

Data was processed using computer program Statistica.

\section{Results and discussion}

In table 1. the major production results of Arbor Acres and Redbro chickens at the age of 42 days are presented. Body mass of Arbor Acres and Redbro chickens was analyzedin table on body mass, and realized body masses at the age of 42 days were used for calculation of production index.

Tabele 1. Production traits in chicks of investigated genotypes

\begin{tabular}{|l|c|c|c|}
\hline Genotype/Traits & Mortality & Feed coversion & Performance index \\
\hline Arbor Acres & 3.80 & 1,868 & 206,73 \\
\hline Redbro & 4.20 & 2,052 & 159,29 \\
\hline
\end{tabular}

Arbor Acres chickens at the age of 42 days had lower mortality (3.80\%), better feed conversion (1.868) and higher realized value of production index (206.73) compared to Redbro chickens. Obtained data were in accordance with technological norms for Arbor Acres and Redbro chickens. Arbor Acres chickens were selected on fast growth and rearing in controlled rearing conditions, contrary 
to Redbro chickens which are selected on prolonged growth and rearing in free housing system. Therefore, differences in production results of Arbor Acreas and Redbro chickens were expected and are result of different selection directions.

The effect of genotype, sex and housing system on body mass of fattening chickens is analyzed in table 2.

Chickens of Arbor Acres genotype were considerably heavier in this investigation (1916.22 g) than Redbro chickens (1622.56 g). Realized body masses were slightly lower compared to technological norms of investigated chickens.

As expected, chickens were considerably heavier at the age of 50 days $(1832.33 \mathrm{~g})$ compared to 42 days $(1643.50 \mathrm{~g})$ of age, whereas male chickens $(1892.11 \mathrm{~g})$ were considerably heavier than females $(1646.67 \mathrm{~g})$.

Table 2. Effect of age, genotype, sex and system of production on body mass of chicks

\begin{tabular}{|c|c|c|}
\hline Factor & Body mass, $\mathrm{g}$ & S.D. \\
\hline \multicolumn{3}{|l|}{ Age } \\
\hline 42.day & 1643.50 & 239.05 \\
\hline 50.day & 1832.33 & 313.84 \\
\hline \multicolumn{3}{|l|}{ Genotype } \\
\hline Arbor Acres & 1916.22 & 269.24 \\
\hline Redbro & 1622.56 & 263.65 \\
\hline \multicolumn{3}{|l|}{ Sex } \\
\hline Male & 1892.11 & 306.63 \\
\hline Female & 1646.67 & 247.23 \\
\hline \multicolumn{3}{|l|}{ Production system } \\
\hline House & 1820.33 & 321.88 \\
\hline Free range & 1667.50 & 234.89 \\
\hline \multicolumn{3}{|c|}{ Significance (F test) } \\
\hline Age & \multicolumn{2}{|c|}{$*$} \\
\hline Genotype & \multicolumn{2}{|c|}{$*$} \\
\hline Sex & \multicolumn{2}{|c|}{ * } \\
\hline Production system & \multicolumn{2}{|c|}{$*$} \\
\hline
\end{tabular}

Chickens reared in the facility realized considerably higher body mass $(1820.33$ g) compared to free range chickens $(1667.50 \mathrm{~g})$. In case of all investigated factors, significant difference was expressed in achieved body masses. Obtained data, as well as expressed statistical significances were expected and in accordance with researches of other authors (Grashorn, 2004; Ristic and Damme, 2002; Pavlovski et al., 2002; Milošević et al., 2005; Bogosavljević - Bošković et al., 2003; Pavlovski et al., 2001; Sarica et al., 2004; Petersen, 2004). 
Standard deviations in body mass were high. Technological norms indicate lower values of standard deviations, i.e. higher homogeneity of the flock. However, in research carried out in Serbia, standard deviation in equivalent of variation coefficient of $11-18 \%$ is common and indicates relativelly small sample, presence of extreme values ond normal distribution of the sample.

The effect of genotype, sex and rearing system on carcass yields is presented in table 3 .

Chickens at the age of 50 days had higher carcass yields compared to 42 day old chickens. Carcass yields "traditional processing" and "ready to roast" were signifcantly higher in 50 day old chickens (83.53 and 76.59) compared to carcass yields of chickens at the age of 42 days (82.61 and 75.68). In carcass yield "ready to grill" there was no statistically significant difference established.

Table 3. Effect of age, genotype, sex and system of production on slaughter yield

\begin{tabular}{|c|c|c|c|c|c|c|}
\hline Factor & Traditionaly & S.D. & Ready to cook & S.D. & $\begin{array}{l}\text { Ready to } \\
\text { grill }\end{array}$ & S.D. \\
\hline & dressed car., \% & & $\%$ & & $\%$ & \\
\hline \multicolumn{7}{|l|}{ Age } \\
\hline 42.day & 82.61 & 1.53 & 75.68 & 2.13 & 66.10 & 2.02 \\
\hline 50.day & 83.53 & 1.53 & 76.59 & 1.77 & 66.79 & 2.41 \\
\hline \multicolumn{7}{|l|}{ Genotype } \\
\hline Arbor Acres & 83.36 & 1.64 & 76.71 & 1.86 & 67.30 & 2.31 \\
\hline Redbro & 83.09 & 1.53 & 75.87 & 1.93 & 65.84 & 2.06 \\
\hline \multicolumn{7}{|l|}{ Sex } \\
\hline Mail & 83.59 & 1.50 & 76.41 & 1.88 & 66.82 & 2.49 \\
\hline Femail & 82.86 & 1.60 & 76.17 & 2.00 & 66.32 & 2.08 \\
\hline \multicolumn{7}{|l|}{ Production system } \\
\hline House & 83.36 & 1.55 & 76.56 & 1.95 & 67.13 & 2.19 \\
\hline Free range & 82.96 & 1.63 & 75.76 & 1.82 & 65.45 & 2.12 \\
\hline \multicolumn{7}{|c|}{ Significansy (F-test) } \\
\hline Age & \multicolumn{2}{|l|}{$*$} & \multicolumn{2}{|l|}{$*$} & \multicolumn{2}{|c|}{ N.S. } \\
\hline Genotype & \multicolumn{2}{|l|}{ N.S. } & \multicolumn{2}{|l|}{$*$} & \multicolumn{2}{|c|}{$*$} \\
\hline Sex & \multicolumn{2}{|l|}{$*$} & \multicolumn{2}{|l|}{ N.S. } & \multicolumn{2}{|c|}{ N.S. } \\
\hline Production system & \multicolumn{2}{|l|}{ N.S. } & \multicolumn{2}{|l|}{$*$} & \multicolumn{2}{|c|}{$*$} \\
\hline
\end{tabular}


Chickens of Arbor Acres genotype had higher yields comapred to Redbro chickens. Difference in carcass yield "traditional processing" was not at the level of statistical significance. However, statistically significant differences occurred in yields "ready to roast" and "ready to grill".

Male chickens (83.59) had considerably higher carcass yields "traditional processing" compared to females (82.86). Differences in carcass yields "readty to roast" and "ready to grill" were not at the level of statistical significance. Carcass yields "ready to roast" were higher in male chickens (76.41), and similar values were obtained in carcass yield "ready to grill", where carcass yields of male chickens were 66.82 comapred to female chickens with carcass yields of 66.32 .

Chickens reared in the facility (chicken coop) (83.86) had higher carcass yields "traditional processing". Chcikens at the age of 50 days had higher carcass yields comapred to 42 day old chickens. Carcass yields "traditional processing" and "ready to grill" were considerably higher in chickens at the age of 50 days (83.53 and 76.59) compared to carcass yields of chickens at the age of 42 days (82.61 and 75.68). In carcass yield "ready to grill" no statistically significant difference was established. .

Arbor Acres chickens had higher carcass yields comapred to Redbro chickens. Difference in carcass yield "traditional processing" was not at the level of statistical significance. However, statistically significant differences occurred in carcass yields "ready to roast" and "ready to grill".

Male chickens had considerably higher yields "traditional processing" (83.59) comapred to females (82.86). Differences in carcass yields "ready to roas" and "ready to grill" weren't at the level of statistical significance. Carcass yields "ready to roast" were higher in male chickens (76.41), and similar values were obtained for carcass yield "ready to roast", where yeidls in males were 66.82 comapred to females with value of 66.32 .

Chickens reared in the facility (83.86) had higher yields 'traditional processing" compared to free range chickens (82.96).

Carcass yields in chickens reared in the facility were 76.56 and 67.13 , whereas in chickens reared on free range they were 75.76 and 65.45 and established differences were statistically significant.

\section{Conslusion}

Based on obtained results the following can be concluded:

- Chickens of Arbora Acres genotype at the age of 42 days realized lower mortality, better feed conversion, higher body mass and higher realized value of production index; 
- Chickens of Arbor Acres genotype had higher carcass yields. Statistically significant differences were established in carcass yields "ready to roast" and "ready to grill";

- Male chickens had higher values for all three investigated yields;

- Chickens reared in the facility had higher yields "traditional processing" (83.86) compared to chickens reared on free range (82.96). Carcass yields "ready to roast" and "ready to grill" were considerably higher in chickens reared in the facility.

\title{
Acknowledgements
}

This research is part of the Project EVB: TR-20021 financial supported by Ministry of Science and Technological Development of the Republic Serbia

\section{Uticaj genotipa i sistema držanja na proizvodne rezultate pilića u tovu}

\author{
Z. Pavlovski, Z. Škrbić, M. Lukić, V. Petričević
}

\section{Rezime}

Ispitivanje je obavljeno na po 500 pilića Arbor Acres i Redbro. Prva grupa pilića od po 30 petlića i kokica po genotipu je nakon 12 sati gladovanja zaklana. Druga grupa je ostala u objektu i tovila se da 50. dana. Treća grupa se odgajala do 50.dana u poluintenzivnom sistemu koji je podrazumevao koriščenje objakta $20 \mathrm{~m}^{2}$ i ispust površine $1 \mathrm{~m}^{2} /$ grlo. Ishrana se zasnivala na smeši prekrupe kukuruza, ječma, vitaminsko mineralnog dodatka i $30 \%$ potpune krmne smeše. Svi pilići su nakon završenog tova (50. dan) izmereni i nakon 12 sati gladovanja zaklani. Pilići Arbor Acres su u uzrastu od 42 dana imali manji mortalitet $(3,80 \%)$, bolju konverziju hrane $(1,868)$ i veću ostvarenu vrednost proizvodnog indeksa $(206,73)$ od pilića Redbro. Pilići odgajani u objektu su postigli značajno veću telesnu masu $(1820,33 \mathrm{~g}) \mathrm{u}$ odnosu na piliće sa ispusta $(1667,50 \mathrm{~g})$. Pilića uzrasta 50. dana su imali veće randmane u odnosu na piliće sa 42 dana uzrasta. Randmani "klasična obrada" i "spremno za pečenje" su bili značajno veći kod pilića u uzrastu 50 dana $(83,53$ i 76,59) u odnosu na randmane trupova pilića sa 42 dana $(82,61$ i 75,68). Pilići odgajani u objektu $(83,86)$ su imali veće randmane "klasična obrada" od 
pilića odgajanih na ispustu. Ostali randmani kod pilića su značajno bili veći kod pilića odgajanih u objektu $(76,56$ i 67,13) nego kod pilića na ispust $(75,76$ i 65,45).

\section{References}

BOGOSAVLJEVIĆ - BOŠKOVIĆ S., TOLIMIR N., PETROVIĆ D., DOSKOVIĆ V. (2003): Uticaj genotipa i pola na odabrane paramerte i kvalitet mesa trupova brojlera. Biotechnology in Animal Husbandry, 5-6, 407-412.

GRASHORN M.A., CLOSTERMANNN G. (2002): Mund Schlachtleistung von Broilerherkünften für die Extensivemast. Archiv für Geflugelkunde, 173-181.

GRASHORN M.A. /2004) : Aspects of nutrition and management of meat quality. XXII World Poultry Congress, Istanbul, Turkey. Book of Abstracts,23 ( full text ellectrically published in Participant List \& Fulltext CD ).

HOPIĆ S., PAVLOVSKI Z., VRAČAR S., ĐURĐEVIĆ Z. (1996 ): Proizvodne i klanične karakteristike brojlerskih pilića različitog genotipa. Biotecnnology in Animal Husbandry, 31-39.

LEWIS P.D., PERRY G. S. FARMER L.J.,PATTERSON R.I.S. (1997): Responses of two genotypes of chicken to the diets and stocking densites typicalof UK and Label Rouge production systems: 1. Performance, behaviour and carcass composition. Meat Science, 45, 501-516.

MELO J., MALLO G., MIQUEL M.C., CAPPALETTI C., FERNANDEZ P. (1996): Evaluation of two poultry commercial strains in threefeeding regimes at two slaughter agws. XX World's Poultry Congress, New Delhi, India. Proceedings, IV, 80.

MILOŠEVIĆ N., PERIĆ L., STRUGAR V., ŽIKIĆ D., PAVLOVSKI Z. (2005): Rearing of fattening chiskens on free range and extensivily in chickens coop. $8^{\text {th }}$ International Symposium Modern Trends in Livestock Production, Beograd Zemun, October, Biotechnology in Animal Husbandry, 5-6, 125-136.

PAVLOVSKI Z., MAŠIĆ B. (1983): Konformacija trupova pilića. Kvalitet mesa i standardizacija. Bled. Zbornik radova, 115-126.

PAVLOVSKI Z., HOPIĆ S., SUPIĆ B., MILOŠEVIĆ N. (2001): Sistemi držanja brojlera sa aspekta proizvodnje prirodne i zdrave hrane. Savremena poljoprivreda, 50, 3-4,195-198.

PAVLOVSKI Z., PETROVIĆ M.M., CMILJANIĆ R., LUKIĆ M. (2002): The effect of production system on growth and quality of poultry meat of pure lines and hybrids. Symposia Aus der Forschunfststen Für Tierproduktion, Halle, Kurzfassungen, D29, 229-231. 
PERIĆ L., MILOŠEVIĆ N., ORLIĆ D., SUPIĆ B. (2003): Raising chickens on free range system. 1. Production parameters and health status. Lucrari Stiintifice, Zootehnie si biotehnologii, 360-363.

PETERSEN J.S. (2004): Management and housing system for broilers - effect on welfare and production. XXII World Poultry Congress, Istanbul, Turkey. Book of Abstracts, 384 ( full text ellectrically published in Participant List \& Fulltext CD ).

RISTIĆ M., DAMME K. (2002): Carcass value and meat quality of slow growing broiler lines upon feeding with rations according to organic condition. Mittewilugsblatt BAFF 41, 146, 89-94.

SARICA M., SEKEROGLU A., DEMIRE.,SUIQMEZM., DINQERE. (2004): The comparitions of deep litter, cage and free range system in broiler production under welfare conditions. XXII World Poultry Congress, Istanbul, Turkey. Book of Abstracts, 354 ( full text ellectrically published in Participant List \& Fulltext CD). ŠKRBIĆ Z., PAVLOVSKI Z., LUKIĆ M. (2008): The effect of stocking density on certain slaughter traits of broilers of Cobb genotype. Biotechnology in Animal Husbandry, 1-2, 51-59.

ŠKRBIĆ Z., PAVLOVSKI Z., LUKIĆ M., PERIĆ L., MILOŠEVIĆ N. (2009): The effect of stocking density on certain broiler welfare parameters. Biotechnology in Animal Husbandry, 1-2, 11-23.

VRAČAR S., PAVLOVSKI Z., HOPIĆ S., LUKIĆ M., ŠKRBIĆ Z. (1996): Uporedno ispitivanje proizvodnih osobina brojlerskih pilića različitih genotipova. Nauka u živinarstvu, 3-4, 141-148.

VITOROVIĆ D., PAVLOVSKI Z., ŠKRBIĆ Z., LUKIĆ M., PETRIČEVIĆ V. (2008): Morphometric and biomechanical parameters of tibiotarsus in diferent strain of broilers. Biotechnology in Animal Husbandry, 5-6, 55-61. 